
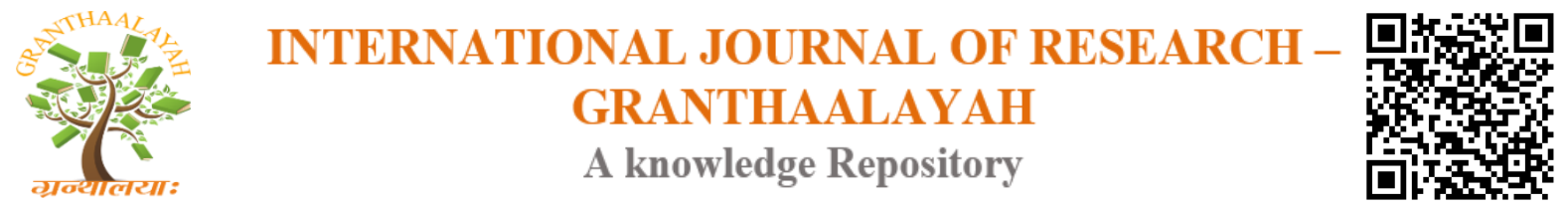

Management

\title{
BENEFITS OF TRAINING AND DEVELOPMENT PROGRAM ON EMPLOYEES' PERFORMANCE: A STUDY WITH SPECIAL REFERENCE TO BANKING SECTOR IN BANGLADESH
}

\author{
Dr. Dhanonjoy Kumar ${ }^{* 1}$, Humaira Siddika ${ }^{2}$ \\ ${ }^{* 1}$ Associate Professor Department of Management, Islamic University, Kushtia, Bangladesh \\ ${ }^{2}$ Research Scholars, Department of Business Administration, University of Kalyani, India
}

\begin{abstract}
Training and development is incredibly vital for ensuring effectiveness of the employees in an organization. The organizations have stretched understood so as to their most precious asset is their human capital where many are convinced for the large investments in employee training and development. This study aims to investigate the significance of training along with development program and its benefits to employees and organization. It focuses on the relative importance of training and development program and their impact on the overall organizational success. To do so, 50 bank employees from Agrani Bank Limited (ABL) have been interviewed through a structured questionnaire. The sample has taken from the Kushtia and Jhenaidah district followed by stratified random sampling. The study has found that training and development program increase the skill, ability and intellectuality of the bank employees. The study also has proposed some suggestions related with the present field.
\end{abstract}

Keywords: Training and Development; Human Capital; Bank; Human Resource Management And Employee.

Cite This Article: Dr. Dhanonjoy Kumar, and Humaira Siddika. (2017). "BENEFITS OF TRAINING AND DEVELOPMENT PROGRAM ON EMPLOYEES' PERFORMANCE: A STUDY WITH SPECIAL REFERENCE TO BANKING SECTOR IN BANGLADESH." International Journal of Research - Granthaalayah, 5(12), 77-88. https://doi.org/10.29121/granthaalayah.v5.i12.2017.475.

\section{Introduction}

Human capital is an important asset for organizations under intense competition. Training and Development function enables human capital to unleash their dexterity. A profound training program acts as a vehicle to enhance employee skills and enable them to perform better in their job. Training and development is indispensable strategic tool for enhancing employee performance and organizations. It aims to improve employee's skills by making them learn new techniques of doing work. Thus, it helps updating their knowledge of doing work which results in increasing their efficiency and hence, results in increasing productivity of an organization. 
Organizations can develop and enhance the quality of the current employees by providing comprehensive training and development. The general benefits received from employee training are: increased job satisfaction and morale, increased motivation, increased efficiencies in processes, resulting in financial gain, increased capacity to adopt new technologies and methods, increased innovation in strategies and products and reduced employee turnover.

Bank is such a type of a financial institution with the intention of collecting society's surplus cash and giving a part of that as a loan to investors for earning a profit. Training is crucial not only to augment the efficiency but also to encourage the workers through letting them know how regarding the importance of their job along with providing the information which is needed to perform their jobs (Elnaga and Imran, 2013). Present study feels the importance of conducting a descriptive research to determine the effect of training and development on employees by giving special emphasis on the banking sector of Bangladesh.

\section{Objectives of the Study}

1) To determine the significance of training and development program on employees' performance.

2) To explore the relationship between training and development on employees' performance.

3) To pinpoint some guidelines for assessing the employees' performance.

\section{Literature Review}

Many researchers have conducted research works on different aspects regarding the impact of training and development programs on bank and other organizations. Several important empirical research findings have been taken into consideration.

Abdullah, H. (2009) in a study discovered that three major challenges to the effective management of Human Resource Training and Development. These include a shortage of intellectual HRD professionals to manage HR Training and Development activities, coping with the demand for knowledge workers and fostering learning and development in the workplace. It is hoped that the findings of this study will provide HR professionals with a clear understanding and awareness of the various challenges in managing effective HR training and development. Hence, relevant and appropriate policies and procedures can be developed and implemented for an effective management of HR Training and Development.

Khan, R. A. G. et.al (2011) in their study concluded that on the job training, training design along with the style of its delivery have significant effect on the organizational performance and all these have positively affect the organizational performance. It means it increases the overall organizational performance.

According to a study conducted by Falola, H. O., Osibanjo, A. O., and Ojo, S. I. (2014) it was revealed that there exists a strong relationship between training and development, employees' performance and competitive advantage. Here, the summary of findings indicates that there lies strong relationship between the tested dependent variable and independent construct. However, 
the bank management should not cave in in their quest to train their staff in order to develop new ideas that will keep improving and retaining employee performance.

Tahir, N. et. al. (2014) identified in their study that training and development is an important aspect of HRM. Thus, it is vital for organization ensuring the presence of skilled and capable employees for improved performance and employees will be than competent when they have the knowledge and skill of doing the task. Training and development would provide opportunities to the employees to make a better career life and get better position in organization. In doing so, organizations efficiency would be increased. On the other hand, employees are the resources and assets of an organization if they are skilled and trained would perform better than those who are unskilled and untrained.

Ampomah, P. (2016) the study found that employees are aware of the purpose of training in the organization, the training objectives are clear to them before the training as well as the selection criteria. The study also found out that employees are motivated through training; and training and development results into higher performance. The study recommended that training and development of all staff should be vigorously pursued and made compulsory.

Olaniyan, D.A. and Ojo, L. B. (2008) in their study concluded that the need for improved productivity has become universally accepted and that it depends on efficient and effective training is not less apparent. It has further become necessary in view of advancement in the modern world to invest in training. Thus the role played by staff training and development can no longer be over-emphasized. Staff training and development are based on the premise that staff skills need to be improved for organizations to grow. Training is a systematic development of knowledge, skills and attitudes required by employees to perform adequately on a given task or job.

Training becomes inevitable the moment an organization realizes the need for improvement and expansion in the job. But often times, organizations embark on job enlargement and enrichment to promote employees' morale, motivation and satisfaction when in the fact the real problem with work performance lies in capacity development.

However, the study results help the management to identify the challenges effects of employees' training on organizational performance, hence determine the areas where improvements through training can be done. It also help the management in planning for the development and implementation of effective and efficient training needs that lead to increased performance of the banks.

No study has found that found that identified the effects of training and development on employees' performance with reference to banking sector very especially in the context of Bangladesh. Thus, the study has motivated to work with the identified gap.

\section{Methodology of the Study}

The study was empirical in nature followed by descriptive research. A research design has been considered for carried out this descriptive study. 
Collection of Data: Both primary and secondary have been used in this study. The primary data have been collected through personal interview by using a structured questionnaire on 50 bank employees from some selected districts of Bangladesh. Secondary data was collected directly by the researcher from different secondary sources like annual reports of selected banks, related books, journals, articles, seminar paper, publications from national and international research institutions, report of different financial institutions, public records and statistics, different research reports etc.

Sampling Design: Stratified random sampling technique was used to collect data from the respondents. To collect response from the employees, the Agrani bank Ltd. in Bangladesh was considered as per convenience of the study. A total of 50 respondents of both male and female were taken from Kushtia and Jhenaidah districts. There are 31 Agrani bank branches situated in Kushtia (21) and Jhenaidah (10) districts (Annual Report, 2015). Out of 31 branches only 10 branches were selected for data collection where 5 branches were from Kushtia and 5 branches were from Jhenaidah. From each district 25 responses were collected separately.

Techniques of Data Analysis: Selected parameters were used to analyze the application of training and development program of Agrani bank Ltd. employees in Bangladesh. All data was processed through computer based Statistical Package for Social Science (SPSS) developed by Nie et al., (1975). Before feeding the data into computer, all data were converted into numerical codes and the details of these coding are recorded in a code book. For conducting this descriptive study, some statistical tools like such as frequency distribution, reliability test and regression analysis were carried out. Here, employees' benefit was considered as dependent variable and there were four independent variables (knowledge development, skill development, performance of the employees and further training improves employees' efficiency).

\section{Conceptual Framework}

Knowledge Development: This involves having the more experienced employees coach the less experienced employees (Devanna, Fombrun and Tichy 1984; McCourt and Eldridge 2003, 256; Torrington et al. 2005, 394 - 395). It is argued that mentoring offers a wide range of advantages for development of the responsibility and relationship building (Torrington et al. 2005, 394 395). The practice is often applied to newly recruited graduates in the organization by being attached to mentor who might be their immediate managers or another senior manager.

Orientation: This is yet another training and development method. This involves getting new employees familiarized and trained on the new job within an organization. During this process, they are exposed to different undertakings for example the nature of their new work, how to take on their identified tasks and responsibilities and what is generally expected of the employees by the organization.

Conferences: As a training and development method involves presentations by more than one person to a wide audience. It is more cost effective as a group of employees are trained on a particular topic all at the same time in large audiences. This method is however disadvantageous because it is not easy to ensure that all individual trainees understand the topic at hand as a whole; not all trainees follow at the same pace during the training sessions; focus may go to 
particular trainees who may seem to understand faster than others and thus leading tot under training other individuals.

Role Playing: Involves training and development techniques that attempt to capture and bring forth decision making situations to the employee being trained. In other words, the method allows employees to act out work scenarios. It involves the presentation of problems and solutions for example in an organization setting for discussion.

Skill Development: Nadler (1984:1.16) noted that all the human resource development activities are meant to either improve performance on the present job of the individual, train new skills for new job or new position in the future and general growth for both individuals and organization so as to be able to meet organization's current and future objectives. There are broadly two different methods that organizations may choose from for training and developing skills of its employees. These are on-the-job training given to organizational employees while conducting their regular work at the same working venues and off-the-job training involves taking employees away from their usual work environments and therefore all concentration is left out to the training. Examples of the on-the-job training include but are not limited to job rotations and transfers, coaching and/or mentoring. On the other hand, off-the-job training examples include conferences, role playing, and many more as explained below in detail. Armstrong (1995) argues that on-the-job training may consist of teaching or coaching by more experienced people or trainers at the desk or at the bench. Different organizations are motivated to take on different training methods for a number of reasons for example; (1) depending on the organization's strategy, goals and resources available, (2) depending on the needs identified at the time, and (2) the target group to be trained which may include among others individual workers, groups, teams, department or the entire organization.

Performance of the Employees: Job rotation and transfers (McCourt and Eldridge 2003, 356) as a way of developing employee skills within organization involves movements of employees from one official responsibility to another for example taking on higher rank position within the organization, and one branch of the organization to another. For transfers for example, it could involve movement of employees from one country to another. These rotations and transfers facilitate employees acquire knowledge of the different operations within the organization together with the differences existing in different countries where the organization operates. On the other hand, it was identified a research that there exists a significant relationship between employees payment and their job satisfaction (Kumar, D. and Siddika, H., 2017).

Employees' Efficiency: These are a number of methods which may be used to develop the skills required within an organization. These course and programs are usually a set of defined and known programs where the contents, durations and all the details about the training are clear to both the organization and the personnel to be trained. Unlike informal trainings and programs, formal training and programs can be planned earlier and also plan for their evaluation. Employees may undertake these courses and programs while completely off work for a certain duration of time or alternatively be present for work on a part-time basis. These programs can be held within the organization (in-house) or off the job. Off the job is argued to be more effective since employees are away from work place and their concentration is fully at training. 
Depending on the knowledge needed, organization's structure and policies, the trainers too may be coming within the corporation or outside the organization.

\section{Benefits of Training Program:}

Training: As one of the major functions within HRM, training has for long been recognized and thus attracted great research attention by academic writers (see e.g. Gordon 1992, Beardwell, Holden and Claydon 2004). This has yielded into a variety of definitions of training. For example, Gordon $(1992,235)$ defines training as the planned and systematic modification of behavior through learning events, activities and programs which result in the participants achieving the levels of knowledge, skills, competencies and abilities to carry out their work effectively. According to McGhee (1996) training therefore can be explained as a planned and systematic effort by management aimed at altering behavior of employees, in a direction that will achieve organizational goals. A formal training program is an effort by the employer to provide opportunities for the employee to acquire job-related skills, attitudes and knowledge.

Development: Krietner (1995) development is "a systematic process of training and growth by which individuals gain and apply knowledge, skills and attitude to manage work organizations effectively". Development perspective examines the current environment, the present state, and helps people on a team, in a department and as part of an institution identify effective strategies for improving performance. In some situations, there may not be anything "wrong" at the present time; the group or manager may simply be seeking ways to continue to develop and enhance existing relationships and job performance. In other situations, there may be an identifiable issue or problem that needs to be addressed; the Development process aims to find ideas and solutions that can effectively return the group to a state of high performance.

The main purpose of training is to acquire and improve knowledge, skills and attitudes towards work related tasks. It is one of the most important potential motivators which can lead to both short-term and long-term benefits for individuals and organizations. There are so many benefits associated with training. Cole (2001) summarizes these benefits as below:

High morale - employees who receive training have increased confidence and motivations;

- Lower cost of production - training eliminates risks because trained personnel are able to make better and economic use of material and equipment thereby reducing and avoiding waste;

- Lower turnover - training brings a sense of security at the workplace which in turn reduces labor turnover and absenteeism is avoided;

- Change management - training helps to manage change by increasing the understanding and involvement of employees in the change process and also provides the skills and abilities needed to adjust to new situations;

- Provide recognition, enhanced responsibility and the possibility of increased pay and promotion;

- Help to improve the availability and quality of staff. 
Figure 1: Proposedmodel of the study

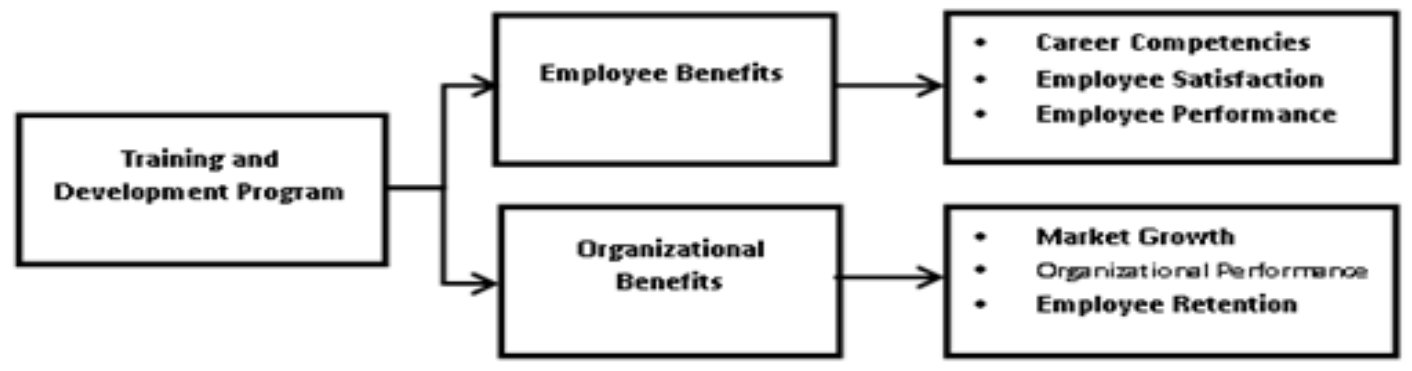

Source: Jehanzeb, K and Bashir, N. A. (2013).

\section{Analysis and Findings}

Table 1: Reliability Analysis of Data

\begin{tabular}{|l|l|}
\hline Cronbach's Alpha & N of Items \\
\hline .774 & 9 \\
\hline
\end{tabular}

Source: Field Survey

From table-1 we see that the Cronbach's alpha value $(\alpha)$ was found 0.774 , which was higher than the minimum acceptable level 0.70 suggested by Nunnally (1978). Thus, the data has found reliable for the study.

Regression Analysis was carried out to determine the relationship between training and development and employees' performance. A null hypothesis has been taken here:

Ho: There is a no relationship between Training and development program and employees' performance.

Table 2: Model Summary

\begin{tabular}{|l|l|l|l|l|}
\hline Model & \multicolumn{1}{c|}{$\mathbf{R}$} & R Square & Adjusted R Square & Std. Error of the Estimate \\
\hline 1 & $.927^{\mathrm{a}}$ & .859 & .846 & .29369 \\
\hline
\end{tabular}

Source: Field Survey

a. Predictors: (Constant), You think further training is needed., Impact of training methods on skill, Impact of training on the performance of the employees, Training help knowledge development.

Table 3: ANOVA $^{\mathrm{b}}$

\begin{tabular}{|ll|l|l|l|l|l|}
\hline \multicolumn{1}{|c|}{ Model } & Sum of Squares & df & Mean Square & F & Sig. \\
\hline 1 & Regression & 23.639 & 4 & 5.910 & 68.517 & $.000^{\mathrm{a}}$ \\
& Residual & 3.881 & 45 & .086 & & \\
Total & 27.520 & 49 & & & \\
\hline
\end{tabular}

Source: Field Survey 
a. Predictors: (Constant), You think further training is needed., Impact of training methods on skill, Impact of training on the performance of the employees, Training help knowledge development.

b. Dependent Variable: From training program employees and organizations will be benefitted. From the ANOVA output it was found that the significance value has come 0.000 which is less than $p$ value (0.05) at 5\% level of significance. For this, null hypothesis has been rejected and it has proved that there exists a significance relationship between Training and development program and employees' performance.

Table 4: Coefficients ${ }^{\mathrm{a}}$

\begin{tabular}{|c|c|c|c|c|c|c|}
\hline \multirow{2}{*}{\multicolumn{2}{|c|}{ Model }} & \multicolumn{2}{|c|}{$\begin{array}{l}\text { Un standardized } \\
\text { Coefficients }\end{array}$} & \multirow{2}{*}{\begin{tabular}{|c|}
$\begin{array}{c}\text { Standardized } \\
\text { Coefficients }\end{array}$ \\
Beta \\
\end{tabular}} & \multirow[b]{2}{*}{$\mathbf{t}$} & \multirow[b]{2}{*}{ Sig. } \\
\hline & & B & Std. Error & & & \\
\hline \multirow[t]{5}{*}{1} & (Constant) & .090 & .094 & & .956 & .344 \\
\hline & $\begin{array}{l}\text { Training helps knowledge } \\
\text { development. }\end{array}$ & 1.005 & .318 & .956 & 3.164 & .003 \\
\hline & $\begin{array}{l}\text { Impact of training methods on } \\
\text { skill development }\end{array}$ & -.031 & .076 & -.035 & -.413 & .682 \\
\hline & $\begin{array}{l}\text { Impact of training on the } \\
\text { performance of the employees }\end{array}$ & -.033 & .102 & -.035 & -.324 & .748 \\
\hline & $\begin{array}{l}\text { Further training improves } \\
\text { employees' efficiency }\end{array}$ & .029 & .300 & .027 & .096 & .924 \\
\hline
\end{tabular}

a. Dependent Variable: From training program employees and organizations will be benefitted.

Source: Field Survey

Tables 2, 3 and 4 represent the regression analysis. The analysis shows that the R-Square value is 0.859. It indicates that a good proportion of variation $(86 \%)$ exists between the dependent variable is explained by the total variation of the 4 independent variables. From all the independent variables significant values of only one variable, like - training helps to knowledge development significant value are less than the $\mathrm{P}$ value 0.05 . It indicates that "Training helps knowledge development" has a significant impact on the bank employees.

Respondents' demographic profile also has been summarized in this study through descriptive statistics which is shown in below:

Table 5: Distributions of the Respondents by Age

\begin{tabular}{|l|l|l|l|}
\hline Age & Frequency & Percent & Cumulative Percent \\
\hline 26 Years to 30 Years & 19 & 38.0 & 38.0 \\
\hline 31 Years to 35 Years & 15 & 30.0 & 68.0 \\
\hline 41 Years to 45 Years & 3 & 6.0 & 74.0 \\
\hline 46 Years to Above & 13 & 26.0 & 100.0 \\
\hline Total & 50 & 100.0 & \\
\hline
\end{tabular}

Source: Field Survey 
The frequency distribution and percentages of the respondents' age (in year) are shown in table 5. The majority of the banks employees, 19 belong to age group of 26-30 years, 15 bank employees belong to the age group of 31-35 years. It is also observed that a moderate number, 13, of bank employees are with age of 46 years and above. Only 03 bank employees belong to age group 41-45 years.

Table 6: Distribution of the Respondents Sex

\begin{tabular}{|l|l|l|l|}
\hline Gender & Frequency & Percent & Cumulative Percent \\
\hline Male & 45 & 90.0 & 90.0 \\
\hline Female & 5 & 10.0 & 100.0 \\
\hline Total & 50 & 100.0 & \\
\hline
\end{tabular}

Source: Field Survey

Of the 50 respondents in this study, 45 were male and 05 were female.

Table 7: Distribution of the Respondents by Experience

\begin{tabular}{|l|l|l|l|}
\hline Experience & Frequency & Percent & Cumulative Percent \\
\hline 1 Years to 5 Years & 31 & 62.0 & 62.0 \\
\hline 6 Years to 10 Years & 3 & 6.0 & 68.0 \\
\hline 11 Years to 15 Years & 4 & 8.0 & 76.0 \\
\hline 16 Years to 20 Years & 1 & 2.0 & 78.0 \\
\hline 21 Years to Above & 11 & 22.0 & 100.0 \\
\hline Total & 50 & 100.0 & \\
\hline
\end{tabular}

Source: Field Survey

As shown in the table 7 , the 11 or $22 \%$ of the respondents were highly experienced (more than 21 years to above). Majority 31 or $62 \%$ respondents have $1-5$ years job experience, 3 or $6 \%$ have the experience of 6-10 years, 4 or $8 \%$ have experience of $11-15$ years, and only 01 or $2 \%$ have the experience of 16-20 years.

Table 8: Distribution of the Respondents Education

\begin{tabular}{|l|l|l|l|}
\hline Education Level & Frequency & Percent & Cumulative Percent \\
\hline Masters and Above Degree & 43 & 86.0 & 86.0 \\
\hline Bachelor Degree & 5 & 10.0 & 96.0 \\
\hline SSC and HSC Pass & 2 & 4.0 & 100.0 \\
\hline Total & 50 & 100.0 & \\
\hline
\end{tabular}

Source: Field Survey

Data in table 8 shows that the majority of the bank employees, 43 or $86 \%$, obtained masters degree and above and 5 or $10 \%$ have bachelor degree. Very few bank employees 2 or $4.0 \%$ are under graduate. 


\section{Managerial Implications}

One interesting finding from the study was identified that training and Development has a crucial impact on the performance of employees with regards to their job. So, there is no doubt that raining is very essentials for all employees. Because its developed employee skill, knowledge, intellectuality and employee's commitment. This is how, organizations need to ensure proper training program in order to breakdown the monotonous situation of the employees and it creates the mental satisfaction which may relates to increase the loyalty and commitment level of the employees in their working environment.

In case of Agrani bank Ltd., presently it increases their expenditure of training courses or workshops which entrusted with the responsibility of designing course curriculum, reading materials, and course contents for conducting training for the purpose of enhancing professionalism and administrative efficiency of the executives and officers of the Bank conducted by Agrani Bank Training Institute (ABTI). In this study, one of the observations of researcher was identified that that there is a positive change among the staff after attending the training. But the employees, who have gone through training, have to be evaluated continuously to understand change in their learning levels. Besides these, Foundation training course also could be applied with importance on the employees of Agrani bank Ltd. for ensuring better interaction among them as well as with the organization.

\section{Recommendations and Conclusion}

Training is an important and imperative tool for the organization to restore the performance of all the personnel for organizational growth and success. It is beneficial to both employers and employees of an organization. An employee will become more efficient and productive if he is trained well. In this study we take the fact of observation that training leads to important benefits for employees and organizations. Throughout this study we can come to a point that it is very beneficial for the organizations to develop the employee development programs. An organized and efficient development program with supportive apparatuses will significantly assist the organizations to retain the most valued human resource, especially those who have a lot of experience with the organization. So, for the organizations, it is also required to evaluate the success of employee training and development program. If organizations are capable to support all employees in meeting their requirements then both, employees and organizations will get the long term benefits. Thus, the implications of our proposed recommendations in the organization could bring a remarkable change in employees' performance which tends to organization efficiency and country's growth as well.

But this study has been carried out with only 50 employees as sample size with respect to Agrani Bank Ltd. within a short period of time. Again, here analysis has carried out limited statistical tools and with only 5 variables which may not enough for a descriptive study. So, our study proposes to conduct further research in broader areas with more sample size in longer time period and more variables by applying some other statistical tools to get more insights. 


\section{References}

[1] Abdullah, H. (2009). Major Challenges to the Effective Management of Human Resource Training and Development Activities, Uluslararası Sosyal Ara_tırmalar Dergisi The Journal of International Social Research, 2(8), 11-25.

[2] Agrani Bank Limited. (2015). Annual Report, 9/D, Dilkusha, Dhaka, Bangladesh.

[3] Ampomah, P. (2016). The Effect of Training and Development on Employee Performance in a Private Tertiary Institution in Ghana"- Case Study: Pentecost University College (Puc)Ghana,Asian Journal of Social Sciences and Management Studies,3(1), 29-33.

[4] Armstrong, M. (1995). A handbook of personnel Management Practices. Kogan Page Limited London.

[5] Beardwell, I., Holden, L. and Claydon, T. (2004). Human Resource Management a Contemporary Approach. 4th Ed. Harlow. Prentice Hall.

[6] Cole, G.A., (2002). Personnel and human resource management. 5th Edn., Continuum London: York Publishers.

[7] Devanna, M. A., Fombrun, C., and Tichy, N. (1984). A framework for Strategic Human Resource Management. In Strategic Human Resource Management 31 - 51. Ed.

[8] Elnaga, A. and Imran, A. (2013). The Effect of Training on Employee Performance. Journal of Business and Management, 5(4), 137-147.

[9] Falola, H. O., Osibanjo, A. O., and Ojo, S. I. (2014)., Effectiveness of Training and Development on Employees'Performance and Organization Competitiveness in the Nigerian Banking Industry, Bulletin of the Transilvania University of Braşov Series V: Economic Sciences, 7 (56)1, 161-170.

[10] Gordon, B. (1992). Are Canadian firms under investing in training? Canadian Business Economics, 1(1), 25-33.

[11] Jehanzeb, K., and Bashir, N. A. (2013). Training and Development Program and its Benefits to Employee and Organization: A Conceptual Study, European Journal of Business and Management, 5(2), 243-153.

[12] Khan, R. A. G,. Khan. F. A. and Khan, M. A. (2011) Impact of Training and Development on Organizational Performance, Global Journal of Management and Business Research, 11 (7), 6268.

[13] Krietner, S. (1995). The good manager's guide. 1st Edn., London: Synene Publishers.

[14] Kumar, D., and Siddika, H., (2017). Perception towards Pay Satisfaction of Bank Employees: A Descriptive Study, International Research Journal of Human Resources and Social Sciences, 4(7), 141-150

[15] McCourt, W. and Derek, E. (2003). Global Human Resource Management: Managing People in Developing and Transitional Countries. Cheltenham, UK: Edward Elgar.

[16] McGhee (1996). Nature of learning. 1st Edn., Boston: McGraw-Hill Book Company.

[17] Nadler, L. (1984). The Handbook of Human Resource Development. New York: John Wiley and Sons.

[18] Nie, N, H. (1975). Statistical Package for the Social Sciences. New York: McGraw- Hill International Edition.

[19] Nunnally, J. C. (1978). Psychometric Theory ( $2^{\text {nd }}$ ed.), New York: McGraw Hill Company.

[20] Olaniyan, D. A., and Lucas. B. Ojo, (2008). Staff Training and Development: A vital tool for Organizational Effectiveness. European journal of Scientific Research 24(3): 326-31.

[21] Tahir, N., Yousafzai, I. K., Jan, S. and Hashim, M. (2014). The Impact of Training and Development on Employees Performance and Productivity A case study of United Bank Limited Peshawar City, KPK, Pakistan, International Journal of Academic Research in Business and Social Sciences, 4(4), 86-98.

[22] Torrington, D., Hall, L., and Taylor, S. (2005). Human Resource Management. 6th Ed. London: Prentice Hall, 394-395. 


\section{Appendix}

Table 1: Training helps to knowledge development

\begin{tabular}{|c|c|c|c|}
\hline Comment & Frequency & Percent & Cumulative Percent \\
\hline Yes & 41 & 82.0 & 82.0 \\
\hline No & 2 & 4.0 & 86.0 \\
\hline No Comments & 7 & 14.0 & 100.0 \\
\hline Total & 50 & 100.0 & \\
\hline
\end{tabular}

Source: Field Survey

Table 2: Impact of training methods on skill development

\begin{tabular}{|c|c|c|c|}
\hline Comment & Frequency & Percent & Cumulative Percent \\
\hline Yes & 36 & 72.0 & 72.0 \\
\hline No & 3 & 6.0 & 78.0 \\
\hline No Comments & 11 & 22.0 & 100.0 \\
\hline Total & 50 & 100.0 & \\
\hline
\end{tabular}

Source: Field Survey

Table 3: Impact of training on the performance of the employees

\begin{tabular}{|c|r|r|c|}
\hline Comment & Frequency & Percent & Cumulative Percent \\
\hline Yes & 38 & 76.0 & 76.0 \\
\hline No & 3 & 6.0 & 82.0 \\
\hline No Comments & 9 & 18.0 & 100.0 \\
\hline Total & 50 & 100.0 & \\
\hline
\end{tabular}

Source: Field Survey

Table 4: Do you think that further training is needed?

\begin{tabular}{|c|c|c|c|}
\hline Comment & Frequency & Percent & Cumulative Percent \\
\hline Yes & 42 & 84.0 & 84.0 \\
\hline No & 1 & 2.0 & 86.0 \\
\hline No Comments & 7 & 14.0 & 100.0 \\
\hline Total & 50 & 100.0 & \\
\hline
\end{tabular}

Source: Field Survey

Table 5: From training program employees and organizations will be benefitted

\begin{tabular}{|c|c|c|c|}
\hline Comment & Frequency & Percent & Cumulative Percent \\
\hline Yes & 40 & 80.0 & 80.0 \\
\hline No & 2 & 4.0 & 84.0 \\
\hline No Comments & 8 & 16.0 & 100.0 \\
\hline Total & 50 & 100.0 & \\
\hline
\end{tabular}

Source: Field Survey

\footnotetext{
*Corresponding author.

E-mail address: djoysk@ yahoo.com
} 